\title{
HISTÓRIA CIÊNCIA
}

Nāo há a menor dúvida que a história é ciência, pois tem leis, se repete e é exata nas relações de causa e efeito.

Que a história se repete, nāo há a mais insignificante dúvida. Desde que as causas sejam as mesmas, as conseqüências têm que ser rigorosamente as mesmas. Caso haja variaçāo nas causas, os efeitos variarāo na mesma proporçāo.

E extremamente difícil a reuniāo de causas exatamente iguais. As probabilidades dessa reuniāo talvez nāo atinja a uma por mil. Talvez, por essa extrema raridade, é que os efeitos dificilmente se apresentam iguais. Uma pequena variaçāo das causas, muitas vêzes em seus aspectos secundários ou na sua coloração apenas, importa em resultados diferentes. Essa aparência de efeitos diferentes engana ao observador menos avisado e êle conclui erradamente que a história nāo se repete! Nāo vê que as causas se modificaram! Que essas causas tomaram outra coloraçāo e, por conseguinte, que as cenas apresentadas devem ser ligeiramente diferentes.

Não obstante isso, vemos a repetição de quadros históricos.

Assim, o Planalto paulista viveu dois séculos e meio, repetindo cem, duzentas, mil vêzes, a mesma situaçāo social, psicológica, demográfica, política, sentimental, econômica, etc. Desde 1550 , que essa regiāo viveu em rigorosa autarquia, causada pelos mesmos complexos irremoviveis de fatôres básicos, até que, em 1796 , pela construçāo da "calçada do Lorena", êsse complexo se alterou $\mathrm{e}$ as consequiências, também, proporcionalmente, se alteraram. A autarquia, inegàvelmente existente no século XVI, continuou nos séculos XVII e XVIII, por que?

Evidentemente, porque as causas continuaram. Houve ou nāo repetiçāo? É evidente que houve repetiçāo! A conseqüência só deixou de se repetir, quando o complexo causal se alterou pela superveniência de novo fator que moditicou a situação.

Até hoje, entretanto, se nāo há uma rigorosa repetiçāo histórica em relaçāo ao Planalto, do que houve nos três primeiros séculos, há entretanto, a conservação evidente de uma certa analogia que empresta à situaçāo planaltina uns certos laivos de autarquia, que, nāo obstante a superveniência da S.P.R. (hoje ferrovia Santos-Jundiaí), da Mayrink-Santos e da via Anchieta, ainda observáveis.

Dessa observaçāo seguida de raciocínio, é facilimo se concluir a lei histórica de que: tôda autarquia social, psicológica, humana, econômica, sentimental, moral, politica, etc., está na razāo direta 
do isolamento geográfico. Cessado êste, por qualquer motivo, ou diminuido, também cessará, ou ver-se-á minorada a autarquia, com projetada diminuiçāo das suas facetas.

Disso resulta uma lei da história, de precisāo matemática, com a exatidāo de uma fórmula quimica. Quantas vêzes êsse complexo causal puder ser aplicado, repetir-se-āo com cronométrica constâncja e com cristalina evidência, as mesmas conseqüências e, por conseguinte as mesmas cenas, os mesmos quadros e as mesmas páginas da história.

Ainda uma repetição de clareza meridiana testemunha a história de Portugal. Em 1385, tivemos uma situaçāo resolvida pela batalha de Aljubarrota. Dois séculos depois, uma situaçāo semethante cenificou-se em Portugal. Então em 1580, Portugal que tinha sua populaçāo modificada, também teve a situaçāo resolvida de forma diametralmente oposta. Por que?

Portugal, em 1385, tinha em sua populaçāo, um certo indice, ou um certo coeficiente eugênico ou em eficiência; ou ainda, tinha uma certa proporção de super-normais.

Nos dois séculos que se seguiram, êsse indice, êsse coeficiente, ou essa proporçāo, por vários motivos, diminuiram ou se amesquinharam e a questão foi resolvida exatamente de maneira oposta. Evidentemente, a populaçāo portuguêsa havia decaído muito! As seleções intersticiais, entre as quais, a operada com a expulsão dos judeus, realizada em 1495, por D. Manuel, a determinada pelas correrias dos navegantes lusos, pelo longínquo Oriente e a resultante da matança de Alcacer-Kibir, em 1578, diminuiram, de tal modo o capital eugênico da populaçāo portuguêsa, que foi possivel a miséria moral de um Cristovão de Moura, o captador dos votos portuguêses, na vergonhosa aclamaçāo de Tomar, quando $\mathrm{Fe}$ lipe II, o rei estrangeiro foi escolhido para a corôa portuguêsa, vaga com a triste e ridícula morte do rei-cardeal $D$. Henrique e a debandada de Alcântara. Êsses acontecimentos eram o atestado mais evidente do fim de raça que era o indice da decadência de Portugal, que tinha a sua populaçāo dessorada pelas seleções.

Disso tudo, conclui-se que todo grupo humano se faz continente de maior ou menor porcentagem de super ou de infra-normais, cousa que determina os eventos da sua história.

Eis uma lei histórica firme como uma rocha, clara como um cristal, observável ante a mais simples inspeçāo e aplicável a todos os casos e explicando muitas ocorrências.

Além destas leis absolutas como causas de situações que a cronologia assinala, a história apresenta centenas de outras, fàcilmente caracterizadas e perceptíveis à mais singela observaçāo interpretativa.

Vejamos:

Nenhum agrupamento humano pode viver permanentemente em civilizaçāo, sem uma fonte de riqueza qualquer a lhe alimentar as 
precisões. Dessa lei da história, se seguem outras, igualmente aplicáveis como fatôres causais de evoluções: cada povo, de conformidade com a graduaçāo de seus rendimentos, tem maior ou menor o seu poder aquisitivo, seu nivel de vida e o seu poder de consumo.

Constitui isso ou nāo uma lei à qual a história obedece e explica uma série de fatos? É claro que se essa lei reaparecer, em igualdade de condições (o que é dificilimo), as conseqüências históricas também se repetirāo, naturalmente diferençadas pela interveniência de outras leis históricas.

A produçāo, qualquer que ela seja, só pode ser levada a efeito se se der a conjunçāo dos seguintes elementos:

Ecologia, compreendendo os ambrentes externos, geográfico e social. O ambiente geográfico compreende o clima, o solo, o sub-solo, a posição geográfica, etc. $\mathrm{O}$ ambiente social abrange o idioma, a religiāo, os costumes, a forma da propriedade, a organizaçāo da familia, a estabilidade da ordem, etc.

Mão de Obra, compreendendo os braços trabalhadores e os cérebros dirigentes empregados na produçāo.

Capital, que é a soma em dinheiro ou nāo, empregada na produçāo.

Consumo, que é o objetivo final da produçāo.

Transporte, que é a locomoçāo do produto do local da produçāo, para o local do consumo. Esse transporte é mais ou menos fácil, se é curto ou longo, se a travessia é amena ou arestosa. Esse transporte varia ainda se êle é terrestre, maritimo, ou de qualquer outra forma.

Qualquer um dêsses fatôres que falte, a produçāo nāo se realizará. Sé um dêles for diminuto, ou se vários dêles se amesquinharem, o total será menor.

Se duas regiões do mesmo país produzirem a mesma cousa, será travada uma competição econômica e vencerá, a regiāo que melhor elaborar o produto e que puder vendê-lo por um preço mais baixo.

Naturalmente isto constitui leis na história, as quais, rigidas, imperativas e imutáveis, obrigam os sucessos que constituem a evoluçāo dos povos. Isso nāo é apenas um jôgo de palavras. A prática confirma repetidamente essa lei que produz nāo apenas conseqüências análogas, mas verdadeira identidade.

Uma singela observação sôbre tôdas as competições econômicas registradas no passado humano constata a veracidade absoluta dessa lei histórica.

$\mathrm{Na}$ História da Civilizaçāo Brasileira nós temos de aplicar essa lei da prndução, desde os mais verdes tempos coloniais. Foi 
ussim que, logo na primeira metade do quinhentismo teve lugar a primeira competição econômica importante pela soma de viscerais conseqüências dela decorrentes. Foi a luta econômica em tôrno do açúcar, entre as capitanias do Nordeste e a capitania vicentina. Foi essa luta resolvida pelo imperatio da invariada lei da produçāo. A aplicaçāo da lei resolveu a pugna econômica em favor do Nordeste, porque esta regiāo dispondo de fatôres de mais vulto, apresentou resultados mais favoráveis sob o ponto de vista econômico.

Esse é um dos magnificos exemplos da firme e inflexível lei hiš́órica, causando de maneira flagrante, importantíssimas consequências que, por sua vez se fizeram causas de fatos de suma eminência.

Assim, São Vicente, em virtude da derrota econômica sofrida, ficou na mais horripilante miséria e a populaçāo, nessa situaçāo, viu-se obrigada, em virtude da lei histórica que obriga a todo o grupo humano civilizado a ter uma fonte de riqueza, a buscar outra regiaão de mais recursos. Nessa emergência, a populaçāo vicentina se internou, à cata de meios de vida. Foi, sem a menor dúvida, a obediência de uma lei da história, a qual nāo podia ser transgredida, sem que se fizesse tombar sôbre os transgressores, - pêso de sua sançāo. Sim, porque como tôda a lei, essa também tinha a sua sanção que consistia em eliminar os individuos recalcitrantes que se insubordinassem contra as suas prescrições.

Com isso, a internaçāo se fêz obrigatória, em oposiçāo visivel ao que ocorria em outros núcleos coloniais. É que em relação a êsses núcleos, não militavam as mesmas circunstâncias vigentes na capitania vicentina.

Enquanto que em Sāo Vicente reinava miséria e a regiāo se fizera inabitável, as capitanias do Nordeste eram ricas e nelas reinava a euforia, graças ao açúcar. É claro que, em Sāo Vicente os moradores tinham que abandonar o ingrato litoral para escapar à morte; enquanto que, no afortunado Nordeste ninguém queria abandonar essa eufórica faixa litorânea que, com o açúcar, causava aos moradores tôdas as bem-aventuranças que uma terra civilizada poderia proporcionar. Dai terem os vicentinos, obrigados pela miséria, se internado, enquanto que os demais ficavam arranhando o litoral, como catanguejos. São conseqüências diferentes da mesma lei aplicada a dois casos antagônicos. Os resultados tinham que ser profundamente diferentes e opostos, até. Enquanto que os nordestinos ficaram grudados à faixa litorânea, apesar das notórias facilidades geográficas para a penetraçāo, os vicentinos entraram para o interior e sem embargo das arestosidades da Serra, vararam todos os obstáculos e penetraram no Planalto paulista. E claro que, se tivessem vencido a luta econômica do açúcar, nāo teriam se afastado do litoral! Nessa internaçāo, defrontaram-se com outra lei regedora da história, a lei da seleção física que elimina 
os sêres de menor capacidade biológica. De fato, pelas tremendas agruras da serra, cujas arestosidades fàcilmente se avaliam, só teriam passado os fortes, isto é, o elemento masculino, o elemento feminino é em regra, o mais delicado e mais frágil. Como conseqüência disto $e$, portanto, de uma lei rigida a comandar os eventos da história, os povoadores filtrados pela seleçāo da travessia da muralha maritima, ligaram-se às mulheres amerindias.

Dessa situaçāo que a Crônica nos apresenta, resultou que, no Planalto paulista a lingua falada era o tupi-guarani, conforme nos diz Sérgio Buarque de Holanda em Raizes do Brasil e a toponimia da terra era, cristalinamente, de origem amerindiana.

Eis uma situaçāo de fato decorrente de uma regra histórica.

Este fato, impulsionado pelas mesmas causas que se repetiam com uma pasmosa constância, durante século e meio, completou a toponímia sertaneja de Sorocaba, de Itú, de Atibaia,.. de Jundiai e do vale do rio Paraiba. Tudo, conseqüência de leis fatais regedoras da história. Mas não foi tudo! O Planalto nāo apresentava nova fonte de riqueza a explorar, de modo que, os moradores, obedecendo ainda a lei da história, acima enunciada, viram-se obrigados a recorrer ao apresamento, que foi a única fonte de riqueza a alimentar o Planalto paulista durante século e meio, possibilitando nessa regiāo, a civilizaçāo e a colonizaçāo, embora estas fôssem de pequeno vulto, na exata proporçāo da fonte de riqueza que era o apresamento.

Enquanto isso, lavrava no Nordeste brasileiro, a intensa euforia do açúcar. E lei regente da história, que as grandes prosperidades econômicas têm o condāo de atrair massas humanas e quantidades de capitais, na proporção do seu valor e do seu volume. E a simples observação de casos concretos que o passado e o presente nos oferecem com uma limpidez de conclusāo, de admirar e uma constância cronométrica de repetições, de pasmar!

Eis porque o Nordeste tangido por essa lei observada em centenas de casos, reuniu e condensou populações, capitais, atenções metropolitanas, cobiças estrangeiras, poder aquisitivo, grande nivel de vida, importante mercado de consumo, etc.

Entre as conseqüências ocorridas no Nordeste, dessa privilegiada situaçāo econômica, havia a cobiça holandesa que alvejava a. feliz Canaā brasileira.

É fácil se depreender que, enquanto a regiāo nordestina era ocupada pelo holandês, o tráfico africano ficou paralisado. Assim acontecendo, a mão de obra que devia ser renovada ininterruptamente, obrigou o nordestino a recorrer à māo de obra indigena para suprir de gente os seus canaviais.

Como é verdadeira uma lei regente da evoluçāo humana, de que a densidade demográfica dos povos selvagens está na razāo direta dos meios de subsistência, temos que, no Nordeste não havia grandes quantidades de indios fora da faixa litorânea, pois a 
regiāo da caatinga e dos campos cerrados não proporciona muitos recursos em alimentaçāo. Daí nāo haver na regiāo, grande dẹnsidade de populaçāo ameríndia. Eis que os padres jesuitas ao levarem a efeito a sua grandiosa obra de catequese, ao criarem na América sulina seu Império teocrático, nāo quizeram se localizar na regiāo nordestina e sim, no sul do Brasil. Isto é sintomático e confirmado pelo fato de nāo haver no Nordeste, antagonismo entre colonos e jesuitas e de nāo se registrar apresamento na regiāo! Assim, o nordestino, sem poder adquirir a mão de obra africana e sem apresar amerindios in-loco, teve de adquirílos no Planalto paulista, que, encontrando mercado de consumo, dedicou-se inteiramente ao apresamento, disso fazendo o seu comércio e a sua fonte de renda.

Por outro lado, o Planalto paulista, isolado do litoral pelos penhascos enristados de Paranapiacaba, nāo podia exportar através de tantos obstáculos, a nāo ser mercadoria humana que se auto-locomovesse. Eis que em estrita obediência de uma lei fixa e inamolgável regente da história, o planaltino só pôde exportar o escravo indio para o Nordeste açucareiro. E, na constância multi- secular dessses eventos, o Planalto viu se repetir a história, com o rigor de uma fórmula quimica ou de uma equação algébrica.

Existe uma lei regente da história humana que diz que nāo é possivel haver produçăo sem māo de obra; o Planalto paulista que a podia fornecer, possibilitou com ela, o enorme desenvolvimento da região nordestina. Existe uma outra lei regente da história humana que ensina que os contactos produ̇zem a influência psicológica reciproca entre as partes que se entrechocam.

$O$ comércio do açúcar entre o Nordeste brasileiro e a Metrópole portuguêsa realizou êsses contactos e, portanto essa regiāo brasileira influenciou-se pelo lusitanismo metropolitano. Essa situação em que o Nordeste aparecia tão colorido de lusitanismo, contrastava de modo gritante com o isolado Planalto que albergava uma população tão divorciada do lusitanismo, quão sem menor contacto com a Metrópole de quem só recebia descaso e esquecimento. Eram sempre as inamolgáveis leis da história que se repetiram constantemente, durante muito tempo.

O Nordeste açucareiro, com a imensa euforia causada pelo açúcar, tinha, por fôrça, de se submeter a essa outra regra histórica, pela qual todo o foco da euforia econômica tem um poder atraidor de gente e de capital. Com isso e, em obediência a uma lei, essa regiāo nordestina se encheu de portuguêses que naturalmente trouxeram o seu espírito metropolitano. Contrastando com essa situação, o Planalto, na sua miséria, nāo tendo foco nenhum atraidor de massas humanas e capitais alienígenas, se apresentava isolado, a falar o guarani, com a sua toponimia indígena e como expoente de um gritante nativismo. 
Como comparação dessa situaçāo que era mera conseqüência das causas apontadas acima, temos que foram os planaltinos os protagonistas dos dois grandes movimentos nativistas do país:

a) A aclamaçāo de Amador Bueno, fracassada, porque a populaçāo masculina de então, nāo pôde ser consultada (1).

b) A guerra dos Emboabas, na qual os planaltinos, representando o elemento nativo, tiveram contra si, os nordestinos aliados dos reinóis, representando o espírito metropolitano (2).

Ao par dessas leis imutáveis e fatais, determinando inapelàvelmerite os sucessos da evoluçāo humana, a história tem normas unicamente possibilitadoras, as quais podem ou nāo causar certos eventos da vida humana. dependendo de outros fatôres sistematizados em normas, ou simplesmente isolados ou casuais. desas.

Entre essas normas possibilitantes estāo as invasões holan-

A norma histórica que deu lugar a que a Holanda tentasse a conquista do Nordeste, está assente em lei da história que diz que todo foco de euforia econômica tem o poder de atração, não só de correntes emigrantistas -de massas humanas e de capitais, como da cobiça imperialística das nações rapínicas que vêm conquistar êsses mesmos focos.

Qualificando ou dando cor, ou ainda completando, em suas minúcias, a causa baseada em lei geral, a norma adjetiva possibilita o evento em relação aos que queiram aproveitar a oportunidade. Em outras palavras, a lei mencionada determina a conquista. Esta constitui o fato substantivo, o principal, o determinador causal. Calcada nessa lei básica se estabelece a norma secundária que completa a principal, possibilitando a oportunidade da conquista ao grupo político que se achar em condições de aproveitá-la.

A história brasileira concretiza exemplos dêsses raciocinios, repetidamente através de vários séculos.

A princípio, a riqueza pau-brasil atraiu a cobiça da França. Eis a lei geral! Tivemos, registradas pela crônica, várias investidas de corsários franceses. Por que franceses? Estes foram os que se aproveitaram da oportunidade. Os franceses nāo venceram! Defendeu-nos, indiretamente, sem o saber e sem o querer, Carlos V. que chamou sobre si, a atenção dos franceses, os quais, sem o rei espanhol e imperador alemāo, teriam vencido.

Depois, no século XVII, o açúcar atraiu o holandês. Foi a repetiçāo do que houve no século XVI. O holandês, nāo tendo quem o detivesse. como aconteceu com o francês, no século anterior, com Carlos V e Felipe II, tomou pé na conquista e nela de-

\footnotetext{
(1). - Vide o Boletim n. 7 da Cadeira de História da Civilização Brasileira da Faculdade de Filosofia, Ciencias e Letras da Universidade de São Paulo.

(2). - Vide o Boletim n.e 8 da mesma Cadeira.
} 
ınorou por um quarto de século. Foi expulso, sòmente pelo esfôrço heróico do nordestino, auxiliado, depois, pela política cromweliana e pela guerra anglo-holandesa de 1651-1655.

Vê-se, com nitidez, a repetição das conseqüências das leis imutáveis que regem a história. A superveniência de outras circunstâncias que emprestam outro colorido e outras formas aparentes e externas aos sucessos, dá a êstes, aspectos vários aos capitulos que consignam fases diferentes do passado humano; o fundo continua o mesmo, apenas variam os aspectos externos e secundários.

Sendo assim. com o cíclo do ouro, deveria se repetir a lëi geral, embora vestida de aparência diversa como se apresentam as circunstâncias.

Foi o que se deu! $O$ ouro, logo de inicio, atraiu sôbre si, a cobiça das nações rapinicas. Era fatal! Tinha que acontecer! A lei geral, regente da história, determinava isso, que se repetia sempre!

Foi o que se deu em 1710 e em 1712, quando Duclerc e Dugay-Trouin atacaram o Rio de Janeiro, porta de entrada da regiāo do ouro. Pouco importa que essas tentativas dêsses franceses tivessem sido, ou nāo, bem sucedidas. Também pouco importam as minúcias que rodearam as tentativas francesas. O que importa é que o ouro, como o pau-brasil, ou o açúcar, causaram, repetidamente, fenômenos perfeitamente idênticos em suas linhas básicas, embora vestidos com roupagens diferentes. Eram já três vêzes que idênticos fenômenos se repetiam.

Outra conseqüência decorrente da prosperidade açucareira que tomou a forma de norma possibilitante, foi a Restauraçāo portuguêsa, em 1640 .

É lei básica regente da história, que tôda prosperidade econômica de uma regiāo qualquer, tende fatal $e$ irremovivelmente a produzir um complexo de acontecimentos politicos. Muitas vêzes, ou quase sempre, essa lei básica só age indiretamente, causando êsses sucessos políticos, de forma que a sua fôrça causal é dificil de ser reconhecida e se faz preciso uma certa agudeza de percepção para desvendá-la. É que essa lei histórica não se apresenta, senāo raramente em sua nudez e quase sempre recoberta de vestes multiformes e policrômicas, variando de aspectos externos, com ilusão mais ou menos completa dos observadores menos avisados.

Eu sou dos que pensam que o fenômeno da euforia açucareira no Nordeste, concentrando nessa afortunada regiāo colonial brasileira, grandes núcleos humanos de intensa atividade produtora $e$ grandes massas de capitais que se remuneravam règiamente, produziu elevado número de conseqüências, muitas delas, politicas $e$, entre estas, a da volta na Metrópole, da soberania portuguêsa, com a ascensão dos Braganças. 
$E$ que os juros da massa enorme de capitais lusos invertidos na riqueza açucareira do Nordeste, acorriam vertiginosos para Lisboa, onde Miguel de Vasconcelos prostituia as velhas glórias lusitanas, aos pés do monarca espanhol, Felipe IV. Êsses jorros continuos de dinheiro, nāo só provenientes dos juros do capital português empatado no Nordeste, mas também das compras feitas em terras lusas pelos nordestinos que entāo possuiam elevadíssimo poder aquisitivo e alto nivel de vida, com grande capacidade de consumo. Para satisfazer as múltiplas precisões dessa afortunada $e$ riquíssima regiāo, seria necessária uma grande importaçāo, o que quer dizer uma exportaçāo elevada de dinheiro.

Enriquecidos com isso, os reinóis teriam podido fazer vitoriosa a restauraçāo de 1640 .

$E$ claro que, por enquantó, por prudência, devemos nos abster de uma afirmativa peremptória, mas que o açúcar produziu qualquer cousa no sentido favorável à Metrópole lusa que havia aplicado seus capitais no Nordeste, parece que nāo resta a menor dúvida.

Então, segundo o que acima ficou afirmado, tôda euforia econômica deve causar fatos de várias naturezas, entre os quais, a politica. Sim, pois se o açúcar causou, a lei deve se repetir com o ouro. Este, sendo o motivo básico de uma euforia econômica nāo pequena, similar perfeita do açúcar, sob o ponto de vista econômico, deveria também produzir resultados similares aos que o açúcar projetou. Sim, se a prosperidade decorrente do açúcar teve o condāo de produzir os resultados políticos que vimos acima, como as leis históricas se repetem em constância impressionante, o ouro, motivo econômico maior que o açúcar, deveria, por maioria de razões, também fazer resultar fenômenos politicos semelhantes aos que haviam decorrido do Nordeste açucareiro; perfeitamente, um resultado similar deveria fatalmente ser produzido pelo ouro. Foi o que aconteceu!

O ouro, descoberto em 1695, tinha que no decorrer da sua mineraçāo e pela colossal euforia dēle derivada, produzir algum fenômeno político na Metrópole, formidàvelmente enriquecida com o ciclo econômico. O fenômeno, a meu ver, resultante do prodigioso enriquecimento decorrente do ciclo do ouro foi o extraordinário fortalecimento do poder real na Metrópole e o absolutismo, o qual com a evoluçáo do século XVIII, foi chamado de despotismo esclarecido. O berço dessa teoria de Estado foi, a meu ver, iniciado em Portugal, tendo sido mera conseqüência do ouro. $O$ primeiro soberano a se beneficiar com a euforia econômica provocada pelo ouro, foi D. Pedro II de Portugal. Esse monarca, com a rica base econômica outorgada pela opulenta mineraçāo brasileira, foi se tornando, progressivamente mais despótico, o mesmo acontecendo com seus descendentes, D. Joāo V (1706-1750), D. José 
(1750-1777) e D. Maria I (1777-1816) e D. Joāo VI (1815-1826). A convocaçāo das Côrtes (democrácia), em 1698, logo depois da descoberta do ouro, só teve a seguir uma nova medida democrática, exatamente cento e vinte e dois anos depois, quando, com o fim do ouro, a Revolução Liberal de 1820 teve lugar. Que extraordinária coincidencia! Exatamente durante o século XVIII que fôra o século do ouro, Portugal năo teve as Côrtes convocadas uma só vez. O povo não foi consultado durante o período do ouro, ficando a responsabilidade dos negócios públicos, ùnicamente com os soberanos que, amparados pelos fartos recursos do ouro, foram se tornando cada vez mais absolutos, de um absolutismo que evoluia em despotismo, a principio sem ser esclarecido, foi se fazendo mais acentuado com Pombal, sendo imitado pelos Bourbons na França, Frederico II na Prussia, Catarina II na Rússia, Carlos III na Espanha, José II na Austria.

Mas nāo é a relaçāo de causa com efeito o que mais ressalta dessa admirável e coincidente paridade. $O$ mais impressionante disso tudo é a conclusāo que se tira, de que cada fonte dé riqueza, ou cada ciclo econômico, ou ainda, cada fase de euforia, causada por alguma grande base econômica, projeta, invariável e repetidamente, fenômenos de várias naturezas, especialmente politicos, os quais têm ressonância por tôda a humanidade, sem ligaçāo aparente com as origens.

Essa mesma repetiçāo constante de leis históricas decorrentes, invariàvelmente, de todos os grandes cíclos econômicos, são de se notar, isto é, por outras palavras, todos os grandes ciclos econômicos produziram resultados simileres, os quais, só nāo foram - iguais, ou idênticos, pela interveniência de outros fatôres que fizeram êsses resultados variar ligeiramente, transformando a identidade em analogia. Nem por isso, os diversos ciclos econômicos que têm bafejado o Brasil com o sôpro da prosperidade têm deixado de regularmente produzir conseqüências análogas.

Baseado nesses raciocínios. em idénticas linhas, evocamos o caso da revolução industrial na Inglaterra. Esta nação, a partir de 1703, por fôrça do tratado de Methuen, ou por fôrça do comércio internacional com Portugal, foi beneficiada, com cêrca de 100 milhões de libras esterlinas (3), que lhe foram injectados, cau1sando, naturalmente, uma grande euforia na sua populaçāo.

Todo o grupo humano que recebe um aumento tāo volumoso na sua capitalizaçāo, tende, naturalmente, a proporcionar um correlato aumento de nível de vida, de poder aquisitivo, etc., o que faz crescer ainda mais, o poder de produçāo.

Isso aconteceu na Inglaterra setecentista, que, dêsse ponto de partida, produziu a Revoluçāo industrial (4).

(3). - Vide J. Lúcio de Azevedo, Fpocas de Portugal Econômico e Simonsen, Histórí Económica do Brasil.

(4). - Simonsen, loc. cit.; Werner Sombart, Le Bourgeois. 
Isso aconteceu nos Estados Unidos, depois que teve lugar o ciclo do algodĩo, no início do oitocentismo, quando teve lugar. em 1849 a mineraçāo do ouro californiano e depois disso, à medida que os diferentes surtos econômicos se vêm projetando na vida norte-americana (5).

Aliás, êsse fenômeno nāo foi uma repetiçāo similar do que houve com a Espanha, nos séculos XVI e XVII, beneficiada com as riquezas da America, e Portugal, no século XVI, enriquecido com as opulências do Oriente. O resultado disso foi o domínio político dos "tercios" espanhóis nos cenários da Europa e a espetaculosa e cintilante cerebração portuguêsa, evidenciada na prodigiosa elite que foram os poetas, escritores, cronistas e mais intelectuais portuguêses dessa época maravilhosa em que esplendorava o flamante mänuelinu.

Compare-se a florescência do quinhentismo português, com o que houve no seiscentismo!

A Inglaterra, enriquecida com os 100 milhões de esterlinos que o Brasil the enviou, teve momentos de fulgurância similar aos que as riquezas americanas haviam proporcionado à Espanha que as refletira nos cenários politicos e nos que as opulências do longínquo e misterioso Oriente haviam bafejado Portugal que as traduzira nos palcos intelectuais e artisticos da cultura mundial.

(5). - A concepsão não é originariamente minha. Encontra-se enunciada pe1a primeira vez, en Werner Sombart, no seu livro "Id Bourgeois". que a publicou, com o fito de encarecer os feitos dos israelitas e não o ouro brasileiro. Depois, a idéia foi retomada por Simonsen que, na sua Historia Economica do 13 rasil, tomo $I$, pg. 44 , a reproduz em parte, dizendo que o ouro brasileiro na Inglaterra. havia causado a Revolucão Industrial. Majs tarde, ainda a notavel ideia de sombart foi publicada em um trabalho do Prof. Vanorden Shaw, no "o Estado de Sĩo Paulo". Eu achei a idéia brilhante e digna de meditação e de aplicaçäo à nossa história.

Reproduzi-a. com a citação adequara, como seria natural e estou firmemente crente de que ela representa unia verdade, tal a sua evidência, apesar de não haver convencido a persistencia conservadora do meu caríssimo amigo, P'rof. Marcondes, ainda teimosamente ligado às obsoletas constata.ções.

Senāo, veiamos:

$O$ ouro brasileiro foi carreado para a Inglaterra, pelo tratado de Methuen (1703), durante os primeiros quarteis do século XViII. Nấo há quem conteste isto que é mencionado comumente pelos próprios historiadores portuguêses. Lis o exemplo de J. Isúcio de Azevedo, F́pocas do Portugal Economico.

Na Inglaterra, é claro que essa avalanche de ouro deveria causar situacōes que se revelariam por qualquer manifestação. Foi o que aconteceu, ensina-nos Sombart, alem de Simonsen e de Vanorden Shall. $\checkmark i d e$ o quadro das invencões no śculo XVIII, que sistematizadas, produziram a revoluçăo da máquina, a qual provocou a revolução industrial.

Nem se diga que a mecanizașão, causando o desemprego, motivou a miśria nas classes operárias. Isso acontecendo por vêzes, não constitui regra geral e principalmente em relação do caso que analisamos. Vejamos:

Não padece a menor dúvida de que a mecanização diminui enormemente a mão de obra en cada fábrica.

Mas o consumo, aumentando em muito maiores proporçoes, obriga a um proporcional incremento da produçáo e esta, para èsse fim, teve evidentemente que multiplicar o total de fábricas.

Foi isso que naturalmente aconteceu com o ouro brasileiro e a Inglaterra nessa época e a sua indústria. Esta, recebendo a injeçĩo do ouro brasileiro, mecanizou-se. 
O acontecido à Inglaterra, no século XVIII, nāo é senāo uma flagrante repetição do que anteriormente havia sucedido a Portugal e à Espanha, com evidenciação de perfeita analogia de resultados.

A Inglaterra assim pletòricamente saturada pelo ouro brasileiro, mecanizou a sua indústria e dentre as múltiplas conseqüências decorrentes dêsse fenômeno, resultaram:

a) Um gasto centuplicado de matéria prima, com o aumento formidável da eficiência da indústria mecanizada. Foi a indústria de fiaçāo e de tecidos, localizada nó Lancashire, a mais beneficiada com as invenções que lhe multiplicaram a produção e o consumo da matéria prima de que resultou 'determinantemente o ciclo do algodāo norte-americano.

b) Uma economia notável de māo de obra, de que para evitar os sem trabalho, houve um registo prodigioso da emigraçāo, a qual se dirigindo para os Estados Unidos, aumentou-lhe a populaçăo da seguinte maneira:

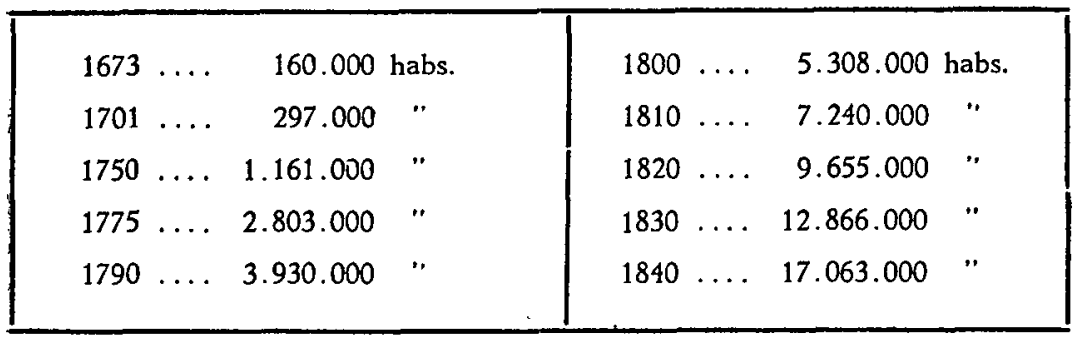

Com o ouro inglês emigrado para os Estados Unidos, afim de ai adquirir matéria prima para satisfazer a fome voraz de sua indústria mecanizada e com a emigraçāo de gente inglêsa para os Estados Unidos, ai foi criado o cíclo do algodāo norte-americano, o qual foi possibilitado pela invençāo do descaroçador mecânico de Ely Whitney, em 1793. Igualmente, graças a isso, a população norte-americana em meio século triplicou o seu total, isto é, aumentou em $300 \%$.

A mecanizaçāo que diminuiu a mão de obra en cada fábrica, ao mesmo tempo, abriu novos mercados de consumo, derrotando produtos congêneres de outra procedência, mais caros, e conquistando o monopólio mundial da produção. Isso, que na.turalmente teve lugar com rapidez meteórica, exigiria grande multiplicação do número de fábricas com a ampliação da indústria, o que evidentemente teria absorvido a mão de obra existente. Mais mão de obra houvesse, teria sido absorvida. A prova disso está no colossal aumento e na urbanização sensivel da populaçāo británica, durante os séculos XVIII e XIX, isto é, depois da mecanização industrial, com o espantoso crescimento das grandes cidades inglessas (Dictionary of Statistics, Mulhall, London, 1909. pg. 444.). No século $\mathrm{XV}$, segundo êsse magnifico dicionário de estatísticas históricas, Londres tinha apenas 35.200 habitantes, seguindo-se-1he, na Inglaterra, York com 11.400, Bristol com 9.200, Plymouth 
Assim enriquecidos, os Estados Unidos tiveram enorme incremento no seu poder aquisitivo e no seu padrāo de vida. Foi uma evidente repetiçāo do que havia acontecido na Inglaterra, durante o século XVIII. Graças a isso tudo, os norte-americanos puderam consumir o nosso café, obrigando maiores remessas do Brasil, para ocorrer ao que a cafeicultura teve que se expandir pelo vale do rio Paraíba arriba e pelo Oeste paulista. Parte do ouro que a Inglaterra tinha mandado para os Estados Unidos, para compras de algodāo, foi transferido para o Brasil, para efetuaçāo de pagamento dessas compras de café. Deu-se, aqui, pois, a repetiçāo do fenômeno inglês, é claro que, em menor escala, mas tāo dinâmico como seus antecessores, como iremos ver mais adiante.

Resumindo o que ficou dito, temos que:

1) Portugal mandou para a Inglaterra grande soma de ouro. Esta, com seu capital assim fortalecido, viu a projeçāo das conseqüências notáveis dêsse fenômeno que, de conseqüência, passou a ser causa.

2) A Inglaterra, tendo mecanizado a sua indústria, removeu para os Estados Unidos, grande parte do ouro recebido, para comprar matéria prima.

3) Os Estados Unidos, enriquecidos com o ouro inglês, remeteram parte dêle para o Brasil, para a aquisiçäo de café para o seu consumo.

Eis três repetições do mesmo fenômeno, produzindo em três pontos geográficos diferentes e em três épocas, diversas conseqüências análogas.

com 7.300, Coventry com 7.200, Norwich com 6.300, Lincoln com 5.500, Canterbury com 4.700, Colchester com 4.500.

Ao findar o século, Londres atingiu o primeiro milhão. I agora na primeira década do século XVIII, isto é, logo a seguir às entradas do ouro brasileiro na Inglaterra, surgiram Newcomen e Savery com suas máquinas atmosféricas. Em 1733, John Kay e Bury inventaram um processo mecánico de tecelagem, com uma lançadeira especial; em 1764, um carpinteiro de Blackburn, de nome James Hargreaves High inventou a Spinning Jenny, aperfeiçoada em 1769, por Richard Arkwright com uma invenção que tomou o nome de water frame a qual era assim denominada, por ser movido a água um bastidor hid̀ráulico.

Em 1779, um tecelão de Bolton. Samuel Crompton. combinou as duas últimas invençoes e produziu o mule, ou o muslin wheel. Em 1785, o clérigo Edmund Cartwright aprimorou os aparelhos de tecer. cousa que, em 1783 tamben havia feito o escocês Bett. Em 1756. Abraham Darby usava em Coalbrookdale, o coke metalúrgico e, lógo em 1760. Smeaton inventou um novo fole mecánico. Em 1740, Benjamin Huntsman de Shefield, melhorou o processo de Henry Cort, sobre a descarbonisação e de fundição do ferro. Em 1769, James Watt produzia $\varepsilon$ máquina a vapor.

Ora essa prodigiosa avalanche de miraculosas invençöes, naturalmente causou um proporcional aumento de eficiéncia e de poderio da. Indústria inglêsa a qual, assim engrandecida e mecanizada, passou a uma produção talvez decuplicada em quantidade e barateada em proporcão. 
O meio rural brasileiro enriquecido como já se viu, pelo advento do ouro anglo-americano, repetiu as conseqüencias ocorridas em tôdas as partes do mundo que também haviam sido enriquecidas.

Uma das conseqüências decorrentes do enriquecimento e da expansío rural da cafeicultura, foi naturalmente o aprimoramento de tôda a aparelhagem agricolà paulista e fluminense, a extensāo das ferrovias, o estabelecimento das cidades, o melhoramento, enfim, de todos os recursos de que dispomos em civilizaçāo.

Foi, sem dúvida, um fenômeno que se repetiu em conseqüências análogas às projetadas por fenômenos similares ocorridos em outras partes do mundo e em outras épocas.

Uma repetição clara na história nos é proporcionada pelo açúcar. Como vimos êsse produto foi tratado logo acima, como tendo sido o fixador da civilizaçāo e riqueza na parte nordestina do Brasil. Em suas linhas gerais e não em suas minúcias, a história se repete, devendo, entretanto, cada caso especial ser estudado, pesquisado, perscrutado e meditado, para que se verifique as similitudes com o caso anterior.

A concorrência da indústria inglêsa assim aparelhada, tinha que matar a inaústria francesa. Seria fatal.!

Por outro lado, os filosofos franceses foram discípulos de Locke, - inglés que, no fim do seiscentismo e no início do setecentismo, escreveu $e$ doutrinou na Inglaterra. Não seria mais natural que a doutrina do grande mestre produzisse algo na Inglaterra? Mas os inglêses estavam económicamente eufóricos, daí a revoluçāo não ter sido feita na Inglaterra e sim na. Franca, onde havia miséria e descontentamento.

Com êsse raciocínio, tira-se a conclusão de que a causa máxima da Rcvolução Francesa foi a Revolução Industrial da Inglaterra e este foi causada pelo ouro brasileiro o qual, como se vê foi um dos responsáveis pelo grande terremoto que se operou na França.

Se pudessemos dosar em algarismos porcentuais o que causou a Revolucão Francesa, calcularíamos em $90 \%$, o yue o futor determinado pela Revolucão Industrial produziu $e$, em apenas en $10 \%$, o resultante do trabalho $\mathrm{e}$ do esforço dos filósofos. Estes teriam agido à. - semelhanca do micróbio que, inoculado em terreno propicio, prolifera e se alastra, dominando o organismo. Foi o que aconteceu na França, no fim do século XVIIII. O terreno em que foram inoculados os germes das idéas dos filósofos, estava preparadíssimo para que êles proliferassem e se alastrassem. A França era como um imenso caldo do cultura, nele, os micróbios se multiplicaram e dominaram o organismo. Caso o caldo de cultura nāo existisse, ainda que inoculassem no orcanismo uma dose microbiana mil vêzes maior do que teve lugar na Irrança, nesse último quartel do século $\lambda$ Vill, nada resultaria.

A Inglaterra teve Locke, grande filósofo, pioneiro e mestre de todos os mestres franceses, verdadeira "fábrica de micróbios psicológico-revolucionarios". Entretanto, nada houve na Inglaterra; é que os ingreses estavam eufóricos e não tinham que se revoltar contra a ordem de cousas reinante. Tudo lhes sorria. Hoje em dia, pode-se observar idéntico processo. O micróbio do conuunismo vinlra sendo inoculado no organismo russo, mas não conseguia se alastrar no regime csarista. Foi preciso que durante a primeira cuerra mundial, a Rússia ficasse em tal estado de miseria económica e moral causada pelo esfor ço bélico e pela derrota, para que os germes dissolventes de Karl Mlarx, manobrados por Lenine e Trotsky, dominassem o organismo russo. Caso não houvesse precisão de terreno favorável para o desenvolvimento de um micróbio ideológico, seria de se verificar a proliferação do marxismo na Inglaterra, ou nos Isstadus unidos e mesmo na França, na Bélgica, na Suiça, ou na Itália. İntretanto, tal nāo se dá, o que vem confirmar as minhas palavras acima. 
O açúcar, conforme essa regra, vimos porque êle atingiu o auge da sua potencialidade povoadora, civilizadora, enriquecedora, produtora de conseqüências, etc. no século que foi de 1550 , até 1660, mais ou menos. Depois disso, o declinio! (6).

Houve absoluta repetiçāo das normas concorrenciais da Economia, atuando na História, a determinar êsse declinio. Entretanto, os fatôres determinadores dêsse declínio foram outros. $\mathrm{Na}$ primeira competição econômica do açúcar, essa que fixou o produto no Nordeste, o fator decisivo, como vimos, foi a distância, parte do fator que eu convencionei chamar de Ecologia. Por mais de um século, o Nordeste brasileiro, graças aos fatôres da produçāo, conjugados harmoniosamente em uma eqüaçāo algébrica, teve o monopólio da produçāo açucareira mundial. Mas, por volta dos meados do século XVII, na Inglaterra, Cromwell iniciou a politica ultra-nacionalista e a França de Colbert seguiu-lhe os passos. Isto féz terminar o monopólio açucareiro do Nordeste brasileiro e marcou o início do açúcar antilhano, o que determinou o declínio do açúcar brasileiro.

Ainda que, em suás linhas gerais, fôsse uma repetição histórica, o fator decisivo que arrebatou do Nordeste o monopólio mundial do açúcar, não foi mais a distância, porém, o consumo, poịs, por fôrça política de Cromwell e de Colbert, a Inglaterra e a França passaram a consumir açúcar das suas possessões antilhanas; estas, produzindo açúcar, conquistaram, ràpidamente os mercados consumidores europeus, relegando o açúcar do Nordeste brasileiro aos mercados da peninsula Ibérica e às sobras. Com isto, iniciou-se o declínio do açúcar brasileiro, o qual no século XVIII teve a sua queda acentuada pelo ouro, que chamou para si, tôdas as atividades das colonias brasileiras. As Antilhas, durante todo o século XVIII, tiveram grande euforia econômica, com a produçāo e com a exportaçāo do açúcar, porém, com o século XIX, fêz-se sentir nova modificação na cena, o que foi uma nova repetição da história, embora causada por outro fator da eqüaçāo da produçāo. Desta vez, foram os fatôres mão de obra e consumo, os causadores da ruina do açúcar antilhano e o novo surto de euforia nos açúcares brasileiros. A Inglaterra, em 1807 proibia o tráfico e libertava o escravo em suas possessões as quais ficaram sem māo de obra. Por sua vez, a França, a Espanha, a Holanda e a Dinamarca, colocando-se nas guerras napoleônicas, contra a Inglaterra,

(6). - V. Enis Júnior, Boletins da Cadeira de História da Civilização Brasileira da Faculdade de Filosofia, Ciências e Letras da Universidade de São Paulo ns. $3,4,5,6,7,8,9,31$ de 1942 a 1951 . 
tiveram suas comunicações cortadas com os continentes europeu $e$ africano, o que quer dizer, nāo puderam se reabastecer de mão de obra, nem vender para o consumo da Europa, o seu açúcar, cuja produçāo ficou desorganizada até 1830 mais ou menos.

Com isso, a euforia econômica abandonou as Antilhas para vir, novamente, assentar suas bandeiras vitoriosas, no Nordeste brasileiro e no Planalto paulista. Logo, porém, vibravam novamente no açúcar brasileiro um golpe semelhante ao do século seiscentista.

Eis mais uma flagrante repetição da história, calcada em leis gerais da economia, embora as pequenas minúcias fôssem diferentes! Constata-se, dessa repetiçāo, a mais flagrante identidade!

$O$ café também oferece motivos que nos asseguram a repetiçāo da história. Eis duas situações perfeitamente iguais, produzindo resultados também perfeitamente iguais. Vejamos:

Em 1727; o café foi importado por Melo Palheta, para Belém do Pará. Por que nāo se estabeleceu êsse produto nesse norte brasileiro, carreando para' aí tôdas as suas formidáveis consequiências? $E$ que the faltavam condições propícias, a principal das quais, o consumo, pois, a América inglêsa que mais tarde foi a região consumidora do café, ainda estava na sua primeira infância com menos de milhāo de habitantes, sem algodăo, sem ouro, sem nivel de vida e sem poder aquisitivo. O café dormiu, nesse extremo Norte, durante meio século!

Depois, em 1770 , a rubiácea foi levada para o Rio de Janeiro pelo magistrado Castelo Branco. $A_{i}$, catalèpticamente, o café dormiu mais meio século; perduravam as mesmas condições externas da época em que deixara o Pará. Os Estados Unidos ainda nāo ofereciam mercados de consumo para o café do Brasil.

Foi asșim que pudemos constatar uma repetiçāo do capitulo da história do café. Essa repetição encontra-se confirmada pelo que se seguiu a isto. Mais ou menos, em 1825, o café, levado para o vale do rio Paraiba, na parte fluminense, aí se expandiu colossalmente, encontrara tôdas as condições favoráveis; o que antes havia impedido a marcha vitoriosa do café, modificara-se. Os Estados Unidos que the negaram o consumo, então em 1825, mais ou menos, enriqueceram prodigiosamente com o ciclo do algodāo. A população dêsse país vizinho, foi decuplicada. Só então, foi possivel ao café brasileiro sair da modorra em que viveu durante um século.

O meio físico ou geográfico nāo age no homem e nāo atua na história apenas indiretamente através do meio econômico; pois a nossa observação constata que em muitas vêzes essa açāo se faz sentir repetidamente nos protagonistas do passado humano.

Citamos alguns poucos exemplos, dentre os muitos existentes e que poderiam ter sido invocados se nāo alongassem muito êste trabalho, de ação indireta do meio geográfico nos quadros da história, isto é de atuação por intermédio do ambiente econômico. 
Vejamos agora como êsse meio geográfico em constância invariável atua diretamente no homem e nas cenas do seu passado de formas a repetir essas cenas em épocas diferentes.

Sabemos que o clima do Planalto paulista se caracteriza pela intermitência extraordinária de suas temperaturas (7). A açāo dessa climatologia sôbre o homem ou sôbre o conjunto de homens determinando-o a agir na história já foi por mim estudada (8) e por isso não vou aqui repetir o que ficou dito. Reporto-me a êsses dois trabalhos, quase na totalidade do assunto tratado, mas quero invocar suas conclusões, as quais se resumem em que no Planalto se formou um grupo humano super-selecionado fixado no correr dos tempos pela consanguinidade. Esse grupo humano, assim qualificado, produziu o fenomenal capitulo histoòrico do Bandeirismo, com tôdas as suas conseqüências e se fêz digno das palavras de Saint Hilaire que o chamou de Raça de Gigantes.

Êsse capitulo do Bandeirismo nāo teve duraçāo efêmera, pois que êle explendorou vigente por mais de dois séculos, repetindo sempre o seu enorme potencial em eugenia e em eficiência. Com isso, se seque que o homem submetido a essa climatologia, que é perene e imutável, deveria repetir sempre os capitulos maravilhosos de energia e de dinamismo. E o que acontece atualmente e que sempre aconteceu. O fenômeno da abertura da lavoura de café de Sāo Paulo nāo foi senāo a manifestaçāo da continuaçāo da causa que deu motivo as proezas da Raça de Gigantes de SaintHilaire. O Bandeirismo tendo tido início no Planalto de 1550 só em 1750 passou na sua manifestação de eficiência e de superior eugenia. De 1750 a 1850 , a Raça de Gigantes espalhada em grande parte pelas Gerais, por Cuiabá, por Goiaz e alhures, produziu apenas pequenas manifestações do seu dinamismo fora do comum como o pequeno ciclo do açúcar paulista e a sua atuaçāo nas Guerras do Sul, mas em meados do século XIX, ei-la concentrada e pujante a realizar a formaçāo da maravilhosa lavoura cafeeira, o segundo bandeirismo paulista. Essa prodigiosa manifestaçāo de espirito de iniciativa e de energia máscula, durou até 1890 , mais ou menos, quando a mesma fulgurância da soberba Raça de Gigantes transformou o velho burgo anchietano no maior Parque industrial da América do Sul.

Essas manifestações nāo sāo senāo a constância invariável da repetiçāo da história sempre através de formas novas e de variados aspectos. Ao historiador incumbe, porém, nāo examinar o problema ùnicamente no seu exterior, mas aprofundá-lo e verificar bem

(7). - Ari França, Estudo sôbre o clima da bacia de Sño Paulo. Tese de doutoramento publicada no Boletim n. 3 do Departamento de Geografia da Faculdade de Filosofia, Ciências e Letras da Universidade de Sāo Paulo.

(8). - Ellis Junior. Raça de Gigantes. Primeiros troncos paulistas e o cruzamento euro-americano. Cia. Editóra Nacional, série Brasiliana, 1036. 
o que o está causando. Se o fizer, estou seguro, a verdade aparecerá e há de verificar que a história se repete porque a rigidez de suas leis, regras e normas é visivel.

Além dessas normas ùnicamente possibilitadoras e que precisam da interveniência e da cooperação de outras, para determinar fenômenos conseqüentes, pode-se, com facilidade, notar leis absolutas que se repetem sistemàticamente, com pasmosa constância, determinando sempre, consequiências similares.

Essas leis absolutas e indeclináveis, sāo as que se podem formular, com o que sistemática e repetidamente decorre dos grandes ciclos econômicos da história brasileira. O passado do Brasil assinala os grandes ciclos autônomos do açúcar nordestino, do ouro e do café, além de outros ciclos menores autônomos também, como o do pau-brasil, do pastoreio, da pesca, ciclos satélites, embora alguns dêstes se marcassem pelo vulto econômico.

Assim, da constância com que se repetem as consequiencias visiveis em três séculos de observação, de interpretação e de critica, estabelecemos a seguinte lei regente dos acontecimentos da historia:

Todo grande ciclo econômico gera ciclos menores, que orbitam em tôrno do seu astro central, refletindo-lhe a luz, como seguindo-lhe o destino. E como se um sistema sideral se formasse em tôrno de um astro rei, caminhando êste, pela imensidāo dos séculos que a Crônica registra, arrastando na sua peregrinaçāo a multidāo dos pequenos satélites que orbitam em tôrno de sí, refletindo o brilho da sua influência, crescendo, quando o fulgor do astro rei aumenta, aquecendo-se aos raios emitidos do centro solar, esfriando-se e se amortecendo, no declinio do seu sistema, como também, morrendo, com a extinçāo e o fim do seu genitor sideral.

Eis o ciclo do açúcar nordestino que teve um periodo máximo absoluto de um longo século, desde 1550 a 1650 , precedendo um outro, menor em vulto econômico, porém, maior em duraçāo, pois vem desde 1650, com altos e baixos, como ensina Simonsen, na sua Historia Ecónomica do Brasil.

Esse grande ciclo econômico que tantas e tāo valiosas conseqüiêncics projetou, foi como que um grande astro rei a gerar satélites. O telescópio da minha apoucada argúcia não é poderoso e suas fracas lentes não têm o poder de devassar as grandes sombras da imensidão erma dos enormes espaços que a astronomia perscruta. Mesmo assim, apenas armado com a fraqueza dos meus pobres engenho e arte consegui isolar, como satélites do grande ciclo do açúcar nordestino, os seguintes ciclos menores, o que não quer dizer que outros nāo tivessem existido:

a) O cíclo do pastoreio, ou da criaçāo de gado bovino. Este foi mera consequiencia do ciclo do açúcar. Este teve precisão do boi, diretamente para o fabrico do açúcar $e$ 
indiretamente para alimentar com a carne e com os laticínios, a imensa populaçāo dotada de grande poder aquisitivo, adensada no Nordeste, pelo açúcar. $O$ mesmo se poderá dizer do couro.

O Nordeste enriquecido e fortemente povoado pelo açúcar, foi um excelente mercado de consumo para o pastoreio. Sem êste mercado, o pastoreio nāo teria podido existir, por êste motivo, além de outros, esta atividade se localizou em tôrno da zona produtora do açúcar.

b) O ciclo do apresamento que nāo foi, senāo, uma atividade subsidiária do grande astro central: o açúcar. Sem que êste consumisse a māo de obra apresada pelo paulista, nāo teria havido apresamento. A recíproca também é verdadeira. Sem māo de obra amerindia apresada pelos paulistas, nāo teria sido possivel o fabrico do açúcar na escala atingida. As influências sāo reciprocas, entre o centro e o satélite.

c) O ciclo da pesca que oferecia alimentaçāo às populações concentradas no Nordeste.

d) O tráfico negreiro, interrompido durante a ocupaçāo holandesa, mas continuado depois de 1655. Essa atividade também nāo teria tido lugar, caso nāo fôsse o ciclo do açúcar oferecer consumo para a mão de obra conseguida conı o tráfico.

Como já disse acima, outros ciclos dependentes do açúcar, teriam existido. Assinalei, apenas alguns. Outros mais percucientes completarāo a lista, mas a conclusāo que se poderá tirar, continuará sempre invariável, que é de haver o ciclo açucareiro produzido inúmeros ciclos menores, os quais, satélites sem luz própria, porque nada, ou quase nada exportavam para além-mar, orbitavam em tôrno do principal.

Com o ouro deu-se invariàvelmente a mesma cousa. Eram causas idênticas que produziam conseqüências idênticas. É claro que essa identidade de conseqüênciàs produzidas eram assim, apenas em suas linhas básicas. Essa identidade. nem por se revestir de aparências diferentes que poderiam fazer crer que ela seria apenas analogia, poderia deixar de ser reconhecida pela similitude que a imbui e que faz ressaltar o mesmo comportamento dos grandes ciclos econômicos, no sentido de gerar outros menores e subsidiários.

O ciclo do ouro, exatamente como o do açúcar, obedecendo a uma regra uniforme de conduta, gerou os seguintes satélites ou ciclos econômicos menores que, em exata identidade de procedimento em relaçāo aos ciclos subsidiários do açúcar, orbitaram em tôrno do astro rei, o grande ciclo do ouro, acompanhando-o, em tôda a sua marcada trajetoria, assinalando as grandes influências que dêle 
recebiam, declinando com êle, quando a decadência lhe bateu à: porta $e$, se extinguindo com êle, quando a agonia e a morte lhe roubaram a realidade. E verdade que alguns dos ciclos econômicos satélites do ouro, lograram sobreviver ao astro rei do seu sistema sideral, é que êsses satélites, ao se aproximar a ruína do ouro, passaram a orbitar em tôrno de outro sol, ou entāo, adquiriram luz própria.

Eis os ciclos econômicos produzidos pelo ouro:

a) O ciclo do bovino no rio Sāo Francisco. As populaçõe:s: adensadas no território das Gerais, dotadas de elevadíssimo poder aquisitivo, exatamente como na regiāo do Nordeste açucareiro, precisando se alimentar, ofereceram consumo seguro para a carne e os laticínios das manadas de bovinos do rio São Francisco e da Bahia. Êste ciclo, enquanto o ouro ofereceu poder aquisitivo, nivel de vida $e$ poder de compra, às populações das Gerais, pôde ter um seguro mercado de consumo, porém, quando êste mercado de consumo empalideceu, agonizou e morreu, o ciclo desapareceu.

b) Vários produtos do abastecimento das Gerais pela Bahia, através da rota descrita por Antonil. A extinção do ciclo do ouro, no fim do século XVIII, acarretou a decadência dolorosa, de tôda a zona, até o advento da cultura do cacau, muito depois.

c) O ciclo comerciário do Rio de Janeiro, entreposto das Gerais, às quais êsse grande centro importador estava ligado pelo caminho novo. A extinção do ouro, certamente prejudicou imenso a regiāo carioca, porém, a vinda da Côrte portuguêsa, em 1808, com 15 mil fidalgos, atenuou bastante o golpe sofrido.

d) O ciclo da Baixada Fluminense que tinha tôdas as facilidades de atingir as Gerais com seus produtos polimórficos, pelos caminho velho e caminho novo. O fim do ouro acarretou, também, o declínio da Baixada, golpeada de morte, no principio do século XIX, pelo advento do café que lhe arrancou os últimos recursos.

e) O ciclo do açúcar paulista que servia as Gerais, pelas passagens dos rios Camanducaia e Mogi-Mirim. Com o fim do ouro, êsse ciclo nāo morreu, porque conseguiu outros mercados de consumo, através da calçada do Lorena, construida no fim do grande ciclo do ouro.

f) O ciclo do muar, alimentado pelas Gerais, para lhe servir com animais que lhe transportassem os produtos para o seu abastecimento. Com o desaparecimento da mineraçāo, êsse ciclo se manteve até o advento do café, em que en- 
controu novos e abundantíssimos mercados de consumo, como veremos. É inútil dizer que sem o muar, não teria sido possivel o ciclo do ouro, tal maneira está o assunto em claridade.

g) O ciclo do tráfico africano que nāo foi outra cousa senāo uma continuação do que era levado a efeito pelo açúcar.

Se, com o ciclo do ouro pudemos testemunhar uma repetição do que ocorrera com o açúcar, a respeito dos ciclos satélites orbitando em tôrno dêle, com o café, tinhamos que aguardar uma repetiçāo do fenômeno, uma vez que se tinha fixado uma regra que se reproduzia infalivelmente. Foi o que se deu! O ciclo do café repetiu a propósito dos ciclos satélites, a mesma sequiência que havíamos constatado antes, nos dois grandes ciclos anteriores.

O café gerou e fixou vários e pequenos ciclos econômicos, exatamente em identidade de procedimento, com os anteriores. E evidente que muitos dêsses pequenos ciclos satélites não eram os mesmos. Muitos desapareceram! Outros novos surgiram! Mas, o que se faz perfeitamente idêntico, é o procedimento de cada grande ciclo, de criar e de manter um sistema sideral próprio, ou um microcosmo particular. Pouco importa que a coloraçāo de cada um dêsses microcosmos nāo tenha a mesma tonalidade! Pouco importa que cada um dêles nāo apresente similitude de morfologia! $O$ que importa é que todos, uniformemente, durante quatro séculos, vêm, com constância impressionante, repetindo o mesmo procedimento. Eis que, como dissemos, com o grande ciclo do café, nāo podia ser diferente o resultado. De fato, o café, criando e oferecendo consumo para êsses produtos, gerou, ou alimentou os seguintes ciclos satélites, além de outros muitos que nāo menciono, porque neles não fixei minha atenção:

a) Ciclo do muar, anteriormente existente, mas que se foi adaptando às novas circunstâncias próprias do café.

b) Ciclo do tráfico africano, até 1850 .

c) Ciclo rodoviário, com a feitura da estrada da Maioridade. em 1847 e da Uniāo e Indústria, em 1854.

d) Ciclo ferroviário, com a construçāo da Leopoldina e da Central em 1864, bem como da S.P.R. em 1867 e da Paulista em $1872 \mathrm{e}$, das outras ferrovias paulistas.

e) Ciclo imigratório, a partir de 1887 .

f) Ciclo urbano, com a criação das cidades do interior paulista que foram entrepostos e centros abastecedores dos núcleos cafeicultores paulistas.

g) Ciclo do algodāo, criado em virtude das crises do café.

h) Ciclo policultor, também oriundo das crises do café e da pequena propriedade.

i) Ciclo industrial. 
Êstes ciclos econômicos, conseqüências do ciclo magno do café, também se fizeram causas. Assim, o ciclo industrial não produziu a via Anchieta? Todos êsses cíclos mais ou menos volumosos, orbitando em tôrno do grande astro central, eram símiles dos satélites que haviam tido gestação semelhante, em séculos passados. Como eu disse, pouco importam o rótulo, a coloraçāo, a morfologia, o valor quantitativo, etc., dêsses satélites. $O$ que ressalta é a identidade de procedimento, o que autoriza a se concluir a seguinte lei que rege a história:

Todo grande ciclo econômico gera ciclos satélites que orbitam em tôrno de si, seguindo a sorte do seu sistema sideral ou se dispersando para outros sistemas, ou ainda perecendo.

O ciclo econômico do pau-brasil nāo teve identidade com essa lei estabelecida, porque:

a) Nāo teve vulto. Foi minúsculo e só é mencionado pela Crônica, pela falta de qualquer outro motivo.

b) A sua absoluta desvalia como proporcionador de ocupaçāo da terra. Dir-se-á que o ciclo do pau-brasil foi um pequeno ciclo marítimo que apenas arranhou o litoral. Um ciclo nestas condições nāo podia centralizar nada.

O ciclo do tabaco nāo foi mencionado, porque eu nāo o estudei. Entretanto, êle deveria ter produzido as mesmas linhas gerais que os demais.

Do exposto, poderá ser objetado que essa regra é invariável nos ciclos econômicos da história brasileira apenas, que nāo é isso que se observa na história das outras partes do mundo. Nāo terá razāo a objeçāo, se pensarmos na observaçāo crítica de outros povos. Assim, o ciclo industrial da Inglaterra, no século XVIII, em que foi mecanizado o imenso parque industrial do Lancashire, foi c grande astro centrál de um sistema sideral, do qual era satélite - ciclo do algodão do Sul dos Estados Unidos. A relaçāo causal é evidente e a repetiçāo pela Inglaterra, da lei histórica dos ciclos satélites, é de meridiana clareza. Também o é o procedimento do cíclo da prata na América espanhola, no século XVI. Essa atividade econômica, nāo só gerou imensa fonte de riqueza, nāo só produziu consequêencias que se espalharam pelo mundo, mas também foi o astro rei de um grande número de satélites que orbitaram ao seu redor. Um dêsses satélites, foi o ciclo do muar do baixo-Paraná, o qual tomou tanto incremento com o ouro brasileiro, que em 1776, obrigou a Espanha a criar o Vice-Reinado do Prata e centralizou as atenções da política externa luso-brasileira na bacia mencionada. 
Outra lei regente da história, a qual se repete em constância invariável e absoluta, nāo permitindo a menor violaçāo, é a de que é a funçāo que cria o orgāo. A funçāo produtora, quando se dá, exige o orgāo transportador, que só entāo se concretiza. Fazer o orgāo aparecer antes que a funçāo dêle tenha necessidade é procedimento inútil. A história, repetindo-se em centenas de casos similares, autoriza uma generalizaçāo que se faz uma lei, pela sua invariável repetiçāo através dos séculos.

Vejamos alguns exemplos que a história brasileira oferece: o Planalto paulista, nos séculos XVI e XVII, nāo mantinha intercâmbio de vulto com o litoral importador e exportador. A única mercadoria vendida pelo Planalto era o escravo ameríndio que se auto-transportava e portanto nāo havia precisão de caminhos melhorados entre o Planalto e o litoral. A exportaçāo planaltina se fazia pelas trilhas dos indios. O orgāo satisfazia bem a funçāo.

Nesse regime, o Planalto paulista viveu quase três séculos. Eis que no fim do século XVIII, isto é, no fim do III século, agoniza o ouro brasileiro e a produçāo do açúcar paulista que era subsidiária do ouro brasileiro, chegou a ficar à beira de um abismo, pois, acompanhando a marcha descencional e agônica do ouro, iria em busca da ruina inevitável e fatal! Era um negro futuro cheio de sombrias espectativas que emolduravam o pequeno ciclo do açúcar paulista.

Emparedado no Planalto, sem saida para o litoral exportador, o pequeno cíclo do açúcar paulista iria morrer com o ouro que lançava os seus estertores finais. Seria preciso para isso, ao açúcar paulista conseguir novos mercados consumidores que o subtraissem da órbita avelhantada do oúro que morria nas Gerais. A funçāo produtora exigia um orgāo que transportasse a produçāo para novos mercados de consumo (9).

Foi entāo que o governador português da Capitania paulista, - Tenente-general Bernardo José de Lorena, verdadeiro tipo de estadista, com magnifica clarividência, fêz construír a famosa calçada do Lorena que seria o orgāo transportador da produçāo açucareira do Planalto.

Mais tarde, o Planalto paulista foi invadido pelo café, o qual, encontrando amplos mercados consumidores que cresciam proporcionalmente à expansāo norte-americana, teve que se alargar, fato que aumentou enormemente a sua produçāo. A velha calçada do Lorena já nāo mais satisfazia a função produtora e exigiu um novo orgāo. Nessa emergência, um outro estadista, Nicolau de Campos Vergueiro, em magnífico golpe de clarividência, construiu a estrada da Maioridade, em 1847.

(9). - Ellis Júnior, A Economia Paulista no secculo XVIII, Boletim n. ${ }^{\circ} 113$ da Faculdade de Filosofia, Ciencias e Letras da Universidade de São Paulo. 
Mas a expansāo cafeeira para o Oeste, determinada pelo colossal aumento de consumo norte-americano, ao ser o pais vizinho impulsionado pelo ciclo do algodão e pelo ouro californiano; bem como pelo consumo da Europa que se urbanizava e se industrializava, exigia mais vias de acesso ao litoral exportador. A produçāo atraia o transporte! A funçāo produtora gerava o orgāo transportador!

Nāo é essa série continua de constantes repetições invariáveis, uma lei regente da história? Nāo é a rêde rodoviária paulista o orgāo da poliproduçāo da pequena propriedade em nosso Estado? As vias Anchieta e Anhanguera nāo sāo reflexos da indústria? Mas, existe mais, muito mais para confirmar isto!

O pau-brasil e o açúcar nordestino não exigiram caminhos, pois já eram produzidos na estreitíssima faixa litorânea. Nāo precisavam de transportes terrestres, ganhavam imediatamente os navios que os haveriam de transportar em direção ao consumo.

Nāo foi assim que sucedeu com o ouro, que logo na.primeira década se satisfez com o caminho velho e com o chamado caminho de Atibaia. Logo, porém, no início do século XVIII, o ouro, com a sua extraçāo, a populaçāo que vivia nas Gerais, os diamantes e a sua civilizaçāo exigiram um caminho novo e as suas múltiplas variantes. Nāo era a funçāo a criar o orgāo que aparecia no momento exato em que a produção aumentava? E o caminho do Rio Grande do Sul, como orgāo transportador do muar, nāo foi criado pela funçāo produtora do ouro? (10).

Com o café no verde e maravilhoso vale do rio Paraiba, pode-se observar nāo só fenômeno análogo mas idêntico.

A princípio, na primeira metade do século XIX, o café se satisfazia com o caminho novo e as suas variantes, então desafogados com o fim do ouro. Mas, com o avanço da sua funçāo produtora, no decorrer da segunda metade do século XIX, eis que surge Mariano Procópio, com sua estrada carroçável, Uniāo e Indústria, construida em 1854. Continuando o aumento da produçāo cafeeira, a funçăo fêz os trilhos da Central, em 1864, como o orgão transportador, chegar a Barra do Pirai, fundada anos antes, em conseqüência da lavoura cafeeira.

Mas, prosseguindo a montante do rio Paraiba arriba, na parte paulista, nos meados do século XIX, a funçāo produtora se fêz vigorosa e dai o orgão tinha que surgir com os caminhos, através da Serra do Mar e os pequenos portos de Parati, Ubatuba, Caraguatatuba e São Sebastiāo.

Além de tudo que foi dito acima, temos dois exemplos dessa regra aplicada ao Planalto paulista, repetidos com intervalos de mais de um século. A princípio, nos primeiros séculos, durante 
mais de duzentos anos, o isolamento determinou a poliproduçāo, pois a falta de comunicação com o mundo exterior impedia a regiāo de receber de fora o que precisava para a sua manutenção em abastecimentos. Dai a região ter de produzir de tudo.

Em meados do século XIX, êsse exemplo se repetiu com exatidão, em relação aos latifúndios cafeeiros isolados no sertāo. É que as causas sendo idênticas (o que em história, dificilmente acontece), as conseqüências tinham fatalmente que ser idênticas. De fato o foram! O isolamento dos latifúndios paulistas, de 1850 a 1880 , mais ou menos, ilhados no adusto sertāo, por uma distância de 200 a 300 quilômetros dos centros de civilizaçāo, produziu autarquias, êsses latifúndios eram obrigados a produzir de tudo, para - seu abastecimento (11).

Eis como, na história brasileira, se pode alinhar mais um caso de repetição.

Não é ùnicamente no campo econômico que se reflete, com invariável constância a repetiçāo dos fatos históricos. $O$ mesmo se observa no terreno social, no político e, também, no cultural, como passaremos a ver:

O apresamento, com suas caracteristicas especiais, determinou uma certa estruturaçāo social, nesse capitulo de atividade.

As mesmas linhas mestras produziram os mesmos resultados. Esforços ordenados fizeram as altas camadas. No Nordeste o açúcar e o patriarcado, com o regime escravocrata, fizeram a opulência $e$ o latifúndio, enquanto que o isolamento autárquico e o apresamento com a poliproduçāo causaram na regiaão planaltina, a miséria e a pequena propriedade, mas, quando o Planalto, como - Nordeste, teve a monocultura canavieira, já no século XVIII e no principio do século XIX, o resultado foi uma absoluta identidade de conseqüências: o latifúndio escravocrata, onde morava uma brilhante aristocracia. Se o latifúndio do Nordeste foi mais opulento, foi devido à agricultura canavieira e à indústria açucareira que, nessa regiāo, tiveram muito mais tempo de exploraçāo, isto é, tiveram mais duraçāo, pois foram três séculos seguidos de continuidade ininterrupta, enquanto que o latifúndio paulista teve existencia de apenas um século, desde 1750 até 1850 .

O ouro, o comércio, o pastoreio, o muar, o café e agora a indústria, produziram conseqüências que, nāo sendo de absoluta identidade, foram, entretanto, similares em suas linhas gerais, podendo se tirar a seguinte lei que se repete uma vez, desde que haja similitude entre os casos que se apresentam: 
Toda atividade econômica produz uma estruturaçāo social determinada proporcionada e de conformidade com os seus delineamentos básicos.

Essa lei se aplica invariàvelmente e se repete, com absoluta regularidade e constância que faria inveja à quimica, física ou à astronomia. Assim, a conseqüência social que se repete invariàvelmente é que a prosperidade decorrente do café produziu, na segunda metade do século XIX, uma brilhante aristocracia rural que se projetou no cenário do Segundo Império e do inicio da República. Isto era repetição exata da aristocracia formada nos canaviais do Nordeste e da similar, constituida nos socavões dourados da mineraçāo.

No terreno político, constatamos a repetiçāo do fenômeno e o estabelecimento e fixaçāo de leis que regem a evoluçāo histórica da humanidade. Não se pode duvidar que o açúcar nordestino tenha causado o maior aportuguesamento das populações da regiāo. Atraidas pela prosperidade açucareira, vinham de Portugal, avalanches de portuguêses que naturalmente traziam o seu espírito metropolitano. O ouro repetiu o fenômeno como cronómetro perfeito. Esse produto precioso atraia milhares de reinóis que anualmente banhavam em ondas de reinolismo a atmosfera psicológica das Gerais.

Como reflexo disto, temos que, tanto o açúcar nordestino, co mo o ouro, atrazaram a independência nacional. Eu já tratei dêsse assunto, com minúcias e, se porventura nāo faço de novo agora, é para nāo repetir (12).

Foi, indiscutivelmente, uma repetição: duas causas similares, produzindo conseqüências também similares. Dessa seqüência, pode-se tirar a seguinte lei histórica, a qual se deve aplicar a casos similares:

Todo o grande motivo econômico (fonte de renda) atraza, em maior ou em menor escala a independência politica das nações co-loniais.

Isso se pode observar repetidamente na história brasileira e é contraprovado pelo sucedido nas Treze Colônias anglo-americanas, onde nāo havia fonte de riqueza semelhante ao açúcar, ou ao ouro. E certo que lá havia o tabaco, importante atraçāo do emigrante metropolitano e portador do espírito europeu. Assim, com tāo apoucados motivos econômicos, em relação ao Brasil, que teve entre outros, o motivo econômico gigantesco, da mineraçāo do ouro e do diamante, as Treze Colonias promoveram com êxito, 170 anos depois do início da colonizaçāo, a proclamaçāo da sua independência.

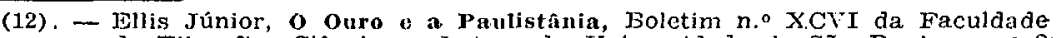
de Filosofia, Ciências e Letras da Universidade de São Paulo e n.o \&: da Cadeira de História da Civilização Brasileira. 
O Brasil levou três séculos para atingir a mesma maturidade dos anglo-americanos e conquistar a sua independência. Por que essa diferença? A resposta está nos raciocínios acima expostos. $O$ Brasil teve grandes motivos econômicos a lhe retardarem a emancipaçāo. Os anglo-americanos, nāo. A formaçāo da alma nacional no Brasil, foi retardada. Os anglo-americanos, em 1776, estavam psicològicamente preparados. Só conseguimos êsse estágio, cinqüenta anos mais tarde, apesar de sermos um século mais antigos que as Treze Colonias. Por êsse motivo acima apontado é que a colonia planaltina paulista teve o seu espirito próprio desenvolvido com mais rapidez do que o de qualquer outra regiäo colonial no Brasil.

$E$ Eue o Planalto paulista nāo teve nenhum motivo econômico que atraisse gente metropolitana. Isolado, assim, formou-se o seu espirito próprio. Seria, pois, natural, e era de se prever que no Planalto paulista tivesse lugar o primeiro movimento de independência. Foi o que aconteceu, pois a aclamaçāo de Amador Bueno foi o primeiro marco assinalador da alma nacional (13).

Nesta publicaçāo especializada citada, ficou demonstrado o raciocínio que me habilitou a chegar à essa conclusão, por isso, eu nāo vou repetir o que já disse.

Eis que a repetiçāo e a perfeita correlaçāo de causa com efeito, nos autorizam a elaborar uma regra histórica aplicável em todos os casos similares.

O café, grande fonte de riqueza, maior ainda que as que o antecederam, também se refletiu no terreno politico, embora nada tcnha influido na evoluçē̄o da situaçāo da Independência. Caso êsse produto tivesse se antecedido de meio século, a. Independência nacional teria, por certo se retardado mais ainda. Se a vinda da Côrte portuguêsa, em $1808 \mathrm{com}$ os seus 15 mil fidalgos e seu espirito reinol foram uma fôrça formidável entravando a psicologia do nativismo, imagine-se o que seria a atmosfera psicológica brasileira, se na ocasiāo tivéssemos um produto como o café, a atrair milhares de reinóis por ano. Esse reinolismo teria fàcilmente engulido e esmagado o nativismo, de modo que seria impossivel a evolução da Independência em 1822.

Justamente, por não haver o café se antecedido, o Brasil perdeu a Cisplatina. Ituzaingó nāo teria sido possivel se o café tivesse facultado recursos ao Tesouro imperial, como mais tarde, em 1850, o fêz, habilitando o Brasil em uma açāo vitoriosa contra Rosas.

Com o ouro, aplica-se a mesma regra e entāo vêmo-lo, graças ao seu imenso poder econômico e demográfico, centralizar o Brasil setecentista, em tôrno do Rio de Janeiro, de Minas Gerais

(13). - Ellis Júnior, Amador Bueno o seu tempo, Boletim n.o 7 da Cadeira de História da Civilização Brasileira da Universidade de São Paulo. 
e de Sāo Paulo, impedindo a desagregaçāo. Se, porventura, a periferia do organismo brasileiro apresentasse um núcleo forte, êste teria se separado. Foi o que aconteceu com a Cisplatina e o que quase sucedeu com o Rio Grande do Sul. Tivesse esta província mais volume, ou estivesse situada mais distante, isolada e sem comunicações, na periferia, teria sido outro o resultado da Farroupilha (14).

$\mathrm{O}$ café, desde meados do século XIX, vai confirmando aquela regra da história. Se o Centro já tinha se solidificado com o ouro, o café ainda mais reforçou aquela situaçāo. Tornando o centro congesto, resumiu o Brasil no centro fluminense-carioca-mineiro-paulista, com uma periferia anêmica, pois o advento da ferrovia ànemisou mais o Rio Grande do Sul, privado da fonte de renda do muar. Com isso, a fôrça centripeta exercida pelo centro, predominou ainda mais. Se houvesse na periferia brasileira algum núcleo volumoso econômica e demogràficamente, êle se teria desgarrado, impulsionado pela fôrça centrífuga. O café teria produzido o desgarramento politico da regiāo em que fôsse localizado, se estivesse na periferia. Essa modalidade de fôrça centrifuga a teria impelido.

A borracha amazônica teria produzido êsse resultado, com um aumento visivel da fôrça centrifuga e com a desagregaçāo da massa periférica, se por acaso o seu cíclo econômico tivesse tido mais duração e pujança.

Essas observações que aí estão resumidas, embora eu pudesse citar dezenas de outras análogas. confirmam as conclusões que elaborei acima, da lei regente dos acontecimentos da história po-

(14). - Aliás. seria interessante uma comparacão entre a situação brasileira em 1.828. a assinar um tratado humilhante, reconhecendo a independência do Iruguai e a que em 183:i-45 assumia o Brasil regencial e imperial. frente aos farroupilhas, a principio arrogantes e francamente senaratistns, mas que depois e aos poucos foram ficando mais tratáveis e se contentando com uma simples Federação, para terminar em 1845, com o nacionalismo anti-rosista de Canabarro.

It quo o café eni 1828 era ainda ausente e o Brasil devido a essa ausência passou pelas forcas caudinas ao assinar o tratado da independência uruguaia. $\mathrm{Fm}$ 1831, o cafe ainda que ausente entretanto ith era uma expectativa que se aproximava vagarosa mas 'seguramente. de modo que em 1845, o café já sendo uma realidade permitia a Caxias falar mais grosso diante de Canabarro. Fm 18.0, Rosas teve que se defrontar com o café já consolidado. Jopez mais tarde foi vencido e o Brasil deve ao café a base da sua espetacular vitoria. Taunay (Historia do Cafe) e Nelson. Werneck (o Panorama do Setrundo Imporio), í dizem que foi o cafe do vale do rio Paraiba. - vencedor da Guerra do Paraguai.

Disso tudo é fácil se concluir a norma vigente em história de que "os corpos politicos-sociais se atraem e se uncm impulsionados pela fôrça centrípeta na razão dîreta das massas econônicas e demopráficas o inversa das distancias que as separam, venciveis pelos meios de comunicacão, medidas em tompo".

Essa regra da história tem invariàvelmente aplicação em muitos casos, entre os quais o que se desenrolou no sul do Brasil no sáculo passado.

A Cisplatina que conseguia um certo volume económico demogréfico, graças ao muar, mercadoria que durante o ciclo do ouro atingiu 
litico-social que, como vimos, se repete, embora cada caso especial deva ser estudado em separado, com a aplicaçāo daquela regra citada.

É inegável outra regra da história, de que a governação municipal de uma regiāo qualquer, se amplia ou se amesquinha, na exata proporçāo do seu isolamento.

Eis o caso de São Paulo, nos dois primeiros séculos. Regiāo isolada e sem comunicações com a Metrópole (15), sem comércio. sem fonte de renda, sem população adensada, etc., foi abandonada por Fortugal e olvidada pelos governadores. Dessa situaçāo constatada pela evoluçāo dos acontecimentos, temos que houve naturalmente um crescimento acromegálico da governança municipal que se foi supletivamente ampliando na medida em que se restringia a governança reinol. Êsse abandôno e, portanto, êsse crescimento acromegálico e supletivo da governança local e municipal, cessou, no século XVIII, com a descoberta do ouro. Portugal passou a dedicar maior atençāo à regiāo pâulistânica e com isso, cessou a causa que fazia ser mais ampla a autogovernança planaltina.

Foi observando êsse fenômeno que Washington Luís afirmou que só então São Paulo reconhecia o domínio português (16).

Dessa situaçāo ocorrida, nāo só no Planalto piratiningano, mas também em muitas regiões similares ou nāo, pode-sé concluir a regra acima enunciada, a qual é aplicável sempre, produzindo resultados análogos aos constatados no Planalto paulista.

um alto nivel de valor e promoveu un certo grau de euforia, tentou e obteve a Independência, por dois motivos conjugados:

a) o Erasil não tinha fonte de renda, de modo que o centro estava em anemia. Fraco esse centro não pode reter a periferia avolumade pelo miuar.

b) A Cisplatina se situava a cêrca de 2.500 a 3.000 quilómetros do Centro ainda amenizado pela demora do café em aparecer.

$\mathrm{Fm}$ 183\%, o Rio Grande do Sul quis repetir a cena a que a Cisplatina com exito levou a efejto, sete anos antes. Então a tentativa não logrou exito. Dois motivos se conjugaram para que o caso riograndense tivesse solução oposta à da Cisplatina. Fra a aplicaşão da mesma jegra histórica em caso diferente. Vejamos esses dois motivos. que são os mesnos modifjcados que atuaram no caso da Cisplatina:

a) O Brasil aos poucos foi tendo uma nova fonte de rencia a alimentar as arcas imperiais, que paulatinamente foram deixando de ser anêmicas e evolutivamente foram se tornando apopléticas.

b) O Rio Grande do Sul embora formando uma região densa e enriquecida pelo muar, estava situado a uma distância muito menor do centro, que cada vez se tornava mais pletórico economica e demograíficamente falando graças ao paulatino advento do caf́s. e por isso não obteve exito na guerra farroupilha, que, aos poucos, foi dominada.

(15). - Vide Ellis Júnior, Boletins da Cadeira de História da Civilização Brasileira da Faculdade de Filosofia, Ciências e Letras da Universidade de São Paulo.

(16). - Washington Luís, A Capitania de Sño Paulo e o Govêrno de D. Rodrigo César. 
Depois de haver percorrido ligeiramente, por alguns capitulos do passado humano, as repetições constatadas nos permitem resumir a questāo, do seguinte modo:

a) Há capítulos históricos que se repetem com absoluta identidade de linhas gerais, produzindo conseqüências absolutamente idênticas. Dessa situaçāo resultam as leis que regem a história.

b) Há, ao lado dêstes, capitulos históricos que se repetem com similitude, mas nāo identidade, produzindo resulțados similares. Dêstes casos originam-se as regras históricas que, embora sem a rigidez das leis da história, conservam delas a imutabilidade.

c) Há também fenômenos históricos que se repetem com analogia, isto é, com mais remota similitude, produzindo conseqüências análogas, ou seja, sem a constância e com menor regularidade que as anteriores. Dêsses casos, têm origem as normas históricas que nāo tendo tanta fôrça quanto as leis e as regras, conservam o poder da orientaçāo da história.

d) Há, entremeados nos fenômenos antecedentes, anteriormente citados, uma série grande de fatos casuais que não se repetem e que apenas qualificam os supra mencionados, colorindo-lhes as minúcias, conformando-lhes os detalhes, mas não desvirtuando-os em suas linhas gerais.

Cada um dos capitulos históricos precisa ser analisado e examinado de per si, para que se verifique bem quais foram as causas que o produziram, as conseqüências dêles projetadas, as leis históricas obedecidas, as regras históricas seguidas ou as normas que lhe orientaram a evoluçāo, bem como as circunstâncias casuais que se fizeram sentir, adjetivando o fato principal. Só depois disso pode-se dizer que o fenômeno histórico está reconstituido ou pelo menos que uma tentativa nesse sentido foi feita.

\section{ALFREDO ELLIS JÚNIOR}

Professor catedrático de História da Civilização Brasileira da Faculdade de Filosofia, Ciencias e Letras da Universidade de São Paulo. 